\title{
Lignin metabolism involves Botrytis cinerea BcGs1- induced defense response in tomato
}

\author{
Chenyu Yang, Yingbo Liang, Dewen Qiu, Hongmei Zeng, Jingjing Yuan and Xiufen Yang*
}

\begin{abstract}
Background: BcGs1, a cell wall-degrading enzyme (CWDE), was originally derived from Botrytis cinerea. Our previous study revealed that BcGs1 could trigger defense responses and protect plants against various pathogens. We researched the defense response mechanism underlying this BcGs1 elicitation in tomato.

Results: We revealed that the two domains were required for BCGs1's full necrosis activity. According to analysis and quantitative real-time PCR of the up-regulated proteins and genes filtered by iTRAQ-based quantitative proteome approach, oxidative metabolism and phenylpropanoid metabolism were speculated to be involved in BcGs1-triggered defense response in tomato. Furthermore, experimental evidence showed that BcGs1 triggered reactive oxygen species (ROS) burst and increased the level of phenylalanine-ammonia lyase (PAL) and peroxidase (POD) enzyme activity, as well as lignin accumulation. Moreover, histochemical analysis revealed that infiltration of BcGs1 in tomato leaves exhibited cell wall thickening compared with untreated plants.
\end{abstract}

Conclusions: The results suggested that BcGs1 activated the basal defense response included lignin metabolism contributed to BcGs1-induced resistance to Botrytis. cinerea infection in tomato.

Keywords: Fungal protein elicitor, Defense response, iTRAQ, Phenylpropanoid, Lignin, Botrytis cinerea

\section{Background}

Plants intimately interact with various microbial pathogens in the complex nature environments. To protect themselves against microbial colonization, plants have evolved a variety of defense mechanisms, including constitutive and inducible resistance strategies. Most potential pathogens are prevented by preformed physical and chemical barriers or after the induction of a complex array of defense responses. In order to Start the relevant resistance system in plants a specific receptor to identify the pathogen is required, at the same time, the plant cell wall-derived molecules may be involved [1]. Following pathogen recognition, which is identified by pathogen-associated molecular patterns (PAMP), microbe-associated molecular pattern (MAMP)-triggered immunity (PTI) or effector-triggered

\footnotetext{
* Correspondence: yangxiufen@caas.cn

The State Key Laboratory for Biology of Plant Disease and Insect Pests/ Key Laboratory of Control of Biological Hazard Factors (Plant Origin) for Agri-product Quality and Safety, Ministry of Agriculture Institute of Plant protection, Chinese Academy of Agricultural science, No. 12 Zhong-guan-cun South Street, Beijing 100081, China
}

immunity (ETI) through immune recognition systems [24], the protein kinase would be activated and ROS would be accumulated $[5,6]$. As a chain reaction, downstream signal including the defense-related genes and PR proteins would be activated $[7,8]$. Plants rely on the basal defense response by using a specific recognition system to prevent penetration and restrict the growth of pathogens, such as cell death, oxidative burst, defense genes, PR protein expression, phytoalexins, callose deposition, lignification and cell wall thickness [2].

To overcome the barrier of the plant cell wall, phytopathogenic fungi secrete various CWDEs, such as cellulases, pectinase, hemicellulases, cutinase and protease. Most of these enzymes not only degrade cell wall components to get carbon sources for pathogen growth but can also trigger multiple plant defense responses.

During infection, necrotrophic pathogens first kill host cells and/or feed on dead tissue. The necrotrophic pathogen Botrytis cinerea often secretes non-host-selective toxins, CWDEs and proteinases to facilitate host cell death [9]. Although plant cell death that resulted from biotrophic 
and necrotrophic pathogen infection plays a central role in multiple defense responses, it has markedly different roles in plant responses to necrotrophs and biotrophs that are dependent on plant-pathogen interaction. The cell death induced by necrotrophic pathogens is more complex than that of biotrophic pathogens in plant immunity because necrotrophic fungi have subtler pathogenic tactics [10]. Variation in multiple basal defense mechanisms is thought to underlie differences in host susceptibility to necrotrophic pathogens. Although the genome of fungus was well-known and Botrytis cinerea biology has been extensively studied [11, 12], the understanding about the biological processes of plants response to Botrytis cinerea is also very limited. Two elicitors isolated from Botrytis cinerea, namely botrycin and cinerein, caused the formation of necrotic lesions, rapid transcriptional activation of genes encoding enzymes of the phenylpropanoid pathway and distinct mitogen-activated protein kinases (MAPKs) in grapevines (Vitis vinifera L) [13]. However, the mechanisms of most secretory elicitors from Botrytis cinerea that trigger the plant defense response are unclear.

CWDEs stimulate multiple immune responses in plants and play a special role in pathogen-host plant interactions, but the mechanism is very complex. Some CWDEs triggering defense responses are associated with their degrading enzyme activity, but some are not related to enzyme activity [14]. Botrytis cinerea-produced polygalacturonases (PGs) and fungal xylanase (Xyn11A) can induce phytoalexin, ethylene and pathogenesis-related protein synthesis and show an immune resistance against Botrytis cinerea [14-17]. Present evidence suggests that these fungal CWDEs trigger typical PTI directly or indirectly through the perception of damage-associated molecular patterns (DAMPs) and through plant cell wall fragments generated by the CWDE degradation [10]. PTI activates a basal defense response, such as the biosynthesis of antimicrobial secondary metabolites (e.g., phytoalexins) and the expression of defense-related proteins, including pathogenesis-related proteins (PR), cell wall lignifications, protease inhibitor expression, and hormone biosynthesis $[18,19]$. Ultimately, plants exhibited broad-spectrum resistance to fungi, bacteria and viruses [16].

Botrytis cinerea, which is one of the most destructive diseases worldwide, is a typical necrotrophic pathogen and causes gray mold disease in tomatoes, strawberries, grapes, cucumbers, soybeans and sunflowers [20]. Resistance breeding efforts have not met with success for botrytis diseases, although genetic resistance is effective and sustainable to protect plants. Elicitors could improve plant resistance to pathogens and are an alternative strategy to reduce plant disease [21]. Understanding the interaction of necrotrophic pathogens and host plants will provide an insight for elicitor application. However, plant basal defense response triggered by many single purified protein elicitors, including BcGs1, has not been clear. In this study, we first described the differential-display defense protein by the iTRAQ method. Based on global differential protein, phenylpropanoid metabolism was implied to be involved in BcGs1-induced tomato defense responses to Botrytis cinerea. Previous studies have shown Phenylpropanoid metabolism played an important role in cotton induced resistance to $V$. dahlia [22]. Meanwhile, the obvious differences including protein expression, lignin metabolism level and cell wall thickening, between BcGs1-induced plants and control were verified in late experiment. This study will help to understand the interaction between necrotrophic fungal pathogens and host plants and provide a theoretical basis for gray mold disease management through elicitor-activating plant immunity.

\section{Methods}

The fungal pathogen cultures and plant cultivates

Botrytis cinerea strain BC-98 was originally isolated from diseased tomato tissues at the Beijing Region, PR China. The fungus was maintained on potato dextrose agar (PDA) medium and cultured in Czapek-Dox liquid medium on a rotary shaker at $25{ }^{\circ} \mathrm{C}$. Tomato seedlings (Zhong za 9, Purchased in Vegetable Flower Research Institute, Chinese Academy of Agricultural Sciences) were grown in a greenhouse at $24-28{ }^{\circ} \mathrm{C}$ with $70-80 \%$ relative humidity, and dark/light ratio was 10/14 h.

\section{Necrosis activity of BcGs1}

Protein BcGs1 was obtained by the method described by Zhang et al. [23]. The necrosis-inducing activity of BcGs1 was observed at $12 \mathrm{~h}$ post injection of tomato, tobacco, cucumber and pea leaves with $1 \mu \mathrm{M} \mathrm{BcGs} 1$ by a $1 \mathrm{ml}$ syringe, while Tris- $\mathrm{HCl}$ buffer $(50 \mathrm{mM})$ was used as a control.

\section{Bioassay for BcGs1-induced disease resistance in tomato} Six to eight tomato plant leaves were injected with $250 \mathrm{nM}$ BcGs1 protein solution $(10 \mu \mathrm{L})$ and Tris- $\mathrm{HCl}$ buffer $(50 \mathrm{mM})$. The same growing leaves were disinfected with alcohol and then rinsed with distilled water at 48, 72, 96, 120 and $168 \mathrm{~h}$ post BcGs1 injection, respectively. The two leaves were placed in a Petri dish with wet filter paper and petiole were moisturize with wet cotton wool. Botrytis cinerea disc was placed on the leaves and incubated for $48 \mathrm{~h}$ under continuous light and $100 \%$ humidity at $25{ }^{\circ} \mathrm{C}$ in a chamber, then lesion diameter was measured using vernier caliper. The induced disease resistance was calculated using the formula: Disease reduction $(\%)=[($ size of lesions on control leaves-size of lesions on elicitor treated leaves)/size of lesions on control leaves] $\times 100$ and the results were analyzed by statistical analysis software. Fifteen tomato plants were used in each treatment and control and three leaves were taken from per plant. Three times were repeated. 


\section{Identification of functional domain of BcGs1}

Biological information analysis showed that BcGs1 contained two domains of Glyco-hydro 15 (GH15) and CBM20_glucoamylase (CBM20). To identify its active structure, the transient expression vector pYBA1152, which contains a fluorescent protein and could fuse to my protein/domains of the protein, was used to express protein BcGs1, GH15 and CBM20 in Nicotiana benthamiana through an Agrobacterium-mediated approach. Fluorescence confocal microscopy and western blot analysis were performed to detect the expression at $48 \mathrm{~h}$ after injection of the recombinant Agrobacterium. At the same time, the necrosis activity was observed with the naked eye.

\section{Western blot}

The sample leaves of Nicotiana benthamiana were collected after injected the Agrobacterium carrying recombinant gene of pYBA1152-BcGs1/GH15/CBM20 $48 \mathrm{~h}$. BcGs1, GH15 and CBM20 gene sequences were constructed to carry a His-tag, respectively. The tree proteins were extracted from the sample, separately, using plant total protein extraction reagent (Purchased from Biotechnology Company). The total proteins were subjected to SDS-PAGE in three lanes after concentration determination and boiling. The PEVD membrane was used to carry the protein glue after SDS-PAGE, the electrotransfer instrument was applied for $1 \mathrm{~h}$ to transfer the proteins to PEVD membrane. The PEVD membrane was incubated with blocking solution for another $2 \mathrm{~h}$ after washing with TBST buffer. Anti-His Tag Mouse Monoclonal Antibody was added and used to bind to His-tag and incubated for $2 \mathrm{~h}$, after that HRP
Conjugated Anti-His Tag Monoclonal Antibody was applied to bind to Anti-His Tag Mouse Monoclonal Antibody for $1 \mathrm{~h}$. The BCIP/NBT was mixed well on PEVD membrane for color. At last, the membrane was put into the instrument to exposure and take pictures.

\section{Differential display protein analysis}

Six to eight tomato plant leaves were injected with $1 \mu \mathrm{M}$ BcGs1 protein solution $(10 \mu \mathrm{L})$, and Tris- $\mathrm{HCl}$ buffer $(50 \mathrm{mM})$ was used as a control. Tomato leaves were collected $24 \mathrm{~h}$ after treatment and used for proteomics detection by iTRAQ (Bangfei Biotechnology, Beijing, China). Each sample was repeated three times. A protein ratio $>1.3$ or $<0.77$ and $P$-value $<0.05$ was regarded as being differentially expressed. Gene ontology (GO) analysis was applied to predict the protein function and calculate the functional category distribution frequency. KEGG analysis was conducted to analyze the functional protein annotation.

\section{Quantitative real-time PCR}

The tomato leaves were injected with BcGs1 and Tris- $\mathrm{HCl}$ buffer. Total RNA was extracted at $0,6,12,24$, 48, 72, $96 \mathrm{~h}$ post treatment according to the protocol of the plant RNA Kit (Tiangen Biotech, Beijing, China). First-strand cDNA was synthesized from the total RNA using SuperMix for qPCR (TransGen Biotech, Beijing, China). The Applied Biosystems7500 Real Time PCR System was used to perform amplification with SYBR Green SuperMix. The primers (Table 1) were designed by Beacon Designer 8.1. Actin, an internal reference, was used to normalize the amount of cDNA in each

Table 1 Primers for quantitative validation of differentially expressed proteins induced by BcGs1

\begin{tabular}{|c|c|c|}
\hline Names & Forward primers $(5->3)$ & Reverse primers $(5$ - > 3) \\
\hline PR1 & ATCATTTGTTCCTTACCTTTG & ACTCCAACTTGTCTACGA \\
\hline PR10 & TTACAAGACAACAACTGAGTAT & AGCGTAGACAGAAGGATT \\
\hline PR-Leaf 4 & GACTATCTTGCGGTTCAC & GCTCTTGAGTTGGCATAG \\
\hline NP24 & TTGTTCTCTTCTTCCTTCTT & GGTGTATGGACAGTTGTT \\
\hline PRSTH-2 & TGTGTTGAAGGATGAAGAA & TAAGCGTAGACAGAAGGA \\
\hline PRSTH-2-like & СTCCACCATCTCCTTGTA & ACACCAATTCGTTTATTTAAGG \\
\hline Endo chitinase EP3 & TGTTGGTTCTACTGATGAT & GGTAATCTGTGTTGTTCTC \\
\hline Glucan endo-1,3- $\beta$-glucosidase B & ATGCTATGTTGGATTCTGTT & TTCTCGGACTACCTTCTTTA \\
\hline Peroxidase1 & ACTTCTCGTGCTAATAACAAT & CAGTAGTTGAGTCTCTTCTTC \\
\hline Peroxidase 12 & GGCTTACTTCGTCTTCATT & GACACAACTTGACCACAT \\
\hline Peroxidase 21 & TGTTATTACCTCTACTTCTTCAC & ATGTTGCCACTTGTTCTT \\
\hline Peroxidase -2 like & GATGTTGTTCGGACCTATA & ATTACTATTCACCTTGCTACA \\
\hline Peroxidase71 & TGTCCTAATGTTGAATCCA & CTCCTGCCAATGATAGAT \\
\hline ACC1 & GTAATGGACACAGTAGAGA & GAGATATTAGAAGTAGGAAGATG \\
\hline Auxin repressed/dormancy associated protein & GATGATGTTATGGCTGGT & GGTACTTGCTAGATCCTTC \\
\hline Actin & GGTGTGATGGTGGGTATGG & GCTGACAATTCCGTGCTC \\
\hline
\end{tabular}


reaction. All the qPCR was repeated three times to calculate the average values for quantification. Each reaction melt curve was analyzed, and a negative control without cDNA template was run with each reaction to evaluate the primer specificity. The relative gene expression levels were calculated from the average values by $\Delta \Delta \mathrm{Ct}$ method.

\section{$\mathrm{H}_{2} \mathrm{O}_{2}$ accumulation and formation in tomato leaves}

$\mathrm{H}_{2} \mathrm{O}_{2}$ production was examined in $6-8$ tomato leaves at 2, 4 , and $6 \mathrm{~h}$ after treatment with $1 \mu \mathrm{M}$ BcGs1 or Tris- $\mathrm{HCl}$ buffer. Leaves were excised and placed in water with $0.01 \%$ Triton-X-100 and $1 \mathrm{mg} / \mathrm{mL}$ nitro $3,3^{\prime}$-diaminobenzidine (DAB); then, the solution was infiltrated with low vacuum pressure for $5 \mathrm{~min}$, and the leaves were incubated overnight at room temperature. After that, the leaves cleared in alcoholic lactophenol (95\% ethanol:lactic acid:phenol, 2:1:1) at room temperature until the leaves did not contain chlorophyll, and they were then rinsed with water. $\mathrm{H}_{2} \mathrm{O}_{2}$ can be visualized by a brownish-red precipitate that formed by polymerization with DAB.

$\mathrm{H}_{2} \mathrm{O}_{2}$ content was detected in the leaves using the $\mathrm{H}_{2} \mathrm{O}_{2}$ Test Kit (Jiancheng Biotechnology, Nanjing, China) at 0, 2, 4, 6, 12, and 24 h post-treatment. Samples of $150 \mathrm{mg}$ were ground using a grinding machine and homogenized in extraction buffer $(0.05 \mathrm{mM}$ Phosphate buffer, $\mathrm{pH}$ 7.2). The supernatant was collected for $\mathrm{H}_{2} \mathrm{O}_{2}$ content detection after centrifugation at $10000 \mathrm{~g}$ for $10 \mathrm{~min}$ at $4{ }^{\circ} \mathrm{C}$. The reagent provided by the kit was incubated with the initial solution following the manufacturer's instructions. The $\mathrm{H}_{2} \mathrm{O}_{2}$ content was detected at $405 \mathrm{~nm}$ wavelength. Each experiment was repeated three times.

\section{Measurement of enzyme activities}

The leaves treated with $1 \mu \mathrm{M}$ BcGs1 and Tris- $\mathrm{HCl}$ buffer (as a control) were collected at $0,12,24,48,72$, and $96 \mathrm{~h}$, frozen in liquid nitrogen immediately and then stored at $-80{ }^{\circ} \mathrm{C}$. One hundred to two hundred mg leaf samples were ground and homogenized in extraction buffer (1.0 mM Phosphate buffer, $\mathrm{pH}$ 7.4). The supernatant was collected for defense enzyme determination following the extraction kit. PAL activity was detected using a PAL Extraction Kit (Jiancheng Biotechnology, Nanjing, China) following the kit's protocol. The supernatant applied to detect POD activity was collected at $3500 \mathrm{~g}$ for $10 \mathrm{~min}$. POD activity was detected at $420 \mathrm{~nm}$ after mixture incubation.

\section{Lignin content detection in tomato leaves}

The thioglycolic acid (TGA) method, a previously described method with modifications [24], was used to evaluate the lignin content in three biological replicates. Tomato leaves treated with $1 \mu \mathrm{M}$ BcGs1 or Tris- $\mathrm{HCl}$ buffer were collected at 12, 24, 48, 72, 96, 120 and $144 \mathrm{~h}$ post BcGs1 treatment. Samples were homogenized and washed with $20 \mathrm{ml}$ phosphate buffer (pH 7.8) and centrifuged at $5000 \mathrm{~g}$ for $10 \mathrm{~min}$ and the process was repeated three times. The pellet was dried at $80{ }^{\circ} \mathrm{C}$ for $24 \mathrm{~h}$. One to two milligram of residue was weighed in tubes, mixed with $1.5 \mathrm{ml} 2 \mathrm{~N} \mathrm{HCl}$ and $0.3 \mathrm{ml} \mathrm{TGA}$, and then incubated at $95^{\circ} \mathrm{C}$ for $4 \mathrm{~h}$ after mixed well. The mixture was rapidly cooled on ice and centrifuged at $10,000 \mathrm{~g}$ for $10 \mathrm{~min}$. The pellet was washed three times with $1 \mathrm{ml}$ distilled water. Pellets were re-suspended with $1 \mathrm{ml}$ $0.5 \mathrm{~N} \mathrm{NaOH}$ and shaken at $200 \mathrm{rpm}$ for $18 \mathrm{~h}$ at room temperature and centrifuged at $15,000 \mathrm{~g}$ for $10 \mathrm{~min}$. The suspension was then transferred into a new tube, and the pellet was washed again with $0.5 \mathrm{ml} 0.5 \mathrm{~N} \mathrm{NaOH}$. After centrifugation, the two supernatants were combined and mixed with $0.3 \mathrm{ml}$ concentrated $\mathrm{HCl}$. The mixture was incubated at $4{ }^{\circ} \mathrm{C}$ for $4 \mathrm{~h}$ to precipitate the lignothioglycolate derivates. After centrifugation, the pellet was solubilized in $1 \mathrm{ml} 0.5 \mathrm{~N} \mathrm{NaOH}$. Absorbance of the resulting solution was measured at $280 \mathrm{~nm}$.

\section{Change of cell wall morphology}

Leaf samples from 6 to 8 leaf tomato plants were embedded using the previously described methods with some modifications [25]. Parts of the leaves around the BcGs1-induced necrotic spots were harvested at $3 \mathrm{~d}$ and $5 \mathrm{~d}$ post induction. Tris- $\mathrm{HCl}$ buffer was used as a control. The samples were then fixed in $1.0 \mathrm{ml}$ phosphate buffer(pH 7.2) containing $2 \%$ glutaraldehyde for $48 \mathrm{~h}$ at room temperature and dehydrated in a graded series of aqueous ethanol solutions (30, 50, 70, 80, 90, 95 and $100 \%$ ethanol) for $15 \mathrm{~min}$ each. The sections were dried overnight at room temperature, mounted on aluminum stubs and sputter-coated with a gold-palladium alloy under a vacuum for $2 \mathrm{~min}$. At last, the sections were observed using a transmission electron microscopy (Hitachi H-7500).

\section{Statistical analysis}

All data provided in this study were from at least three independent replicates. Significant differences between treatments and controls were determined with an analysis of variance using SAS 8.1 software. The means were compared using Tukey's HSD test.

\section{Results}

BcGs1-induced necrosis activity and resistance to Botrytis cinerea in tomato

To investigate the necrosis activity in various host plants, we first obtained protein BcGs1 from the fermentation of Botrytis cinerea according to the method of Zhang, et al. [23]. Purified BcGs1, with $72 \mathrm{kDa}$ of relative apparent molecular weight, displayed a single band 
in the SDS-PAGE (Additional file 1: Figure S1A). The BcGs1 could induce necrosis activity in the tomato, tobacco, cucumber and pea leaves $12 \mathrm{~h}$ post BcGs1 infiltration (Additional file 1: Figure S1B), indicating that BcGs1 has rapid necrosis activity in host plants. To analyze the appropriate induction time for disease resistance against Botrytis cinerea in tomato, fully mature 4-week-old tomato leaves were infiltrated with $0.25 \mu \mathrm{M}$ BcGs1 solution at opposite sides of the central vein, and Tris- $\mathrm{HCl}$ buffer was used as control. Botrytis cinerea disc were inoculated on the detached leaves at 48, 72, 96, 120 and $168 \mathrm{~h}$ after BcGs1 induction. The lesion areas at different induction times were measured using the cross method. BcGs1-treated tomato leaves showed a significant reduction in the lesion area caused by $\mathrm{Bo}$ trytis cinerea compared to the Tris- $\mathrm{HCl}$ buffer control. The smallest lesion area appeared at $72 \mathrm{~h}$, and the lesion area was reduced $23.3 \%$ compared to the control. The result showed that $72 \mathrm{~h}$ was the most suitable induction time of BcGs1 (Fig. 1a, b). Therefore, our research showed that BcGs1 induced significant resistance to Botrytis cinerea in tomatoes with obvious necrotic activity.

Two domains of Glyco-hydro 15 (GH15) and CBM20_glucoamylase (CBM20) are required for BcGs1 full necrosis activity

BcGs1 contains a Glyco-hydro 15 (GH15) domain and a CBM20_glucoamylase (CBM20) domain. To identify the functional domain for necrosis activity, BcGs1, truncated GH15 and CBM20 were expressed transiently in Nicotiana benthamiana leaves via an Agrobacterium-mediated transient expression system. Obvious fluorescence under a confocal fluorescence microscope and western blot indicated that BcGs1, truncated GH15 and CBM20 were expressed in Nicotiana benthamiana leaves. Transient expression of BcGs1 could induce strong necrosis, whereas GH15 induced a faint necrotic response, and CBM20 had no necrotic response (Fig. 2). The result indicated that the two domains are required for the full necrotic activity of BcGs1.

\section{Ifferentially expressed protein analysis of iTRAQ}

To investigate the mechanism of BcGs1-triggered defense response in tomato plants, differential proteomics was performed using the iTRAQ technique. A total of 109 proteins were differentially accumulated. Among them, 71 up-regulated proteins with a fold-change $>1.3(P<0.05)$ and 38 down-regulated proteins with a fold-change $<0.77(P<0.05)$ were identified, while there were 66 function-known proteins (Table 2). GO-based classification was conducted by Protein accession subjected to InterPro and GO annotation. GO functional analysis showed that enriched proteins were involved in molecular functions of binding, hydrolase activity and catalytic activity, in biological processes of metabolism, cellular protein modification processes, transport, regulation of gene expression, response to stress and stimulus, biosynthetic processes, catabolic processes, signal transduction, and so on (Fig. 3a). KEGG pathway analysis showed these differential proteins enriched in metabolic pathways, biosynthesis of secondary metabolites, phenylpropanoid biosynthesis, phenylalanine metabolism, plant-pathogen interactions and plant hormone signal transduction (Fig. 3b).

\section{QRT-PCR analysis of the expression profile of genes encoding differential-display proteins}

Based on the BcGs1-induced differential proteomics analysis, pathogenesis-related proteins, peroxidases, chitins, phenylpropanoid biosynthesis-related proteins, and biosynthesis of secondary metabolite-related proteins were selected and quantitatively confirmed in a biologically

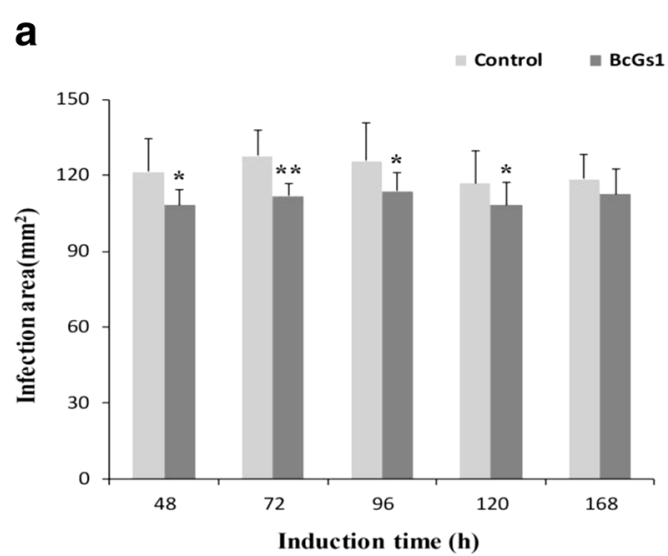

b

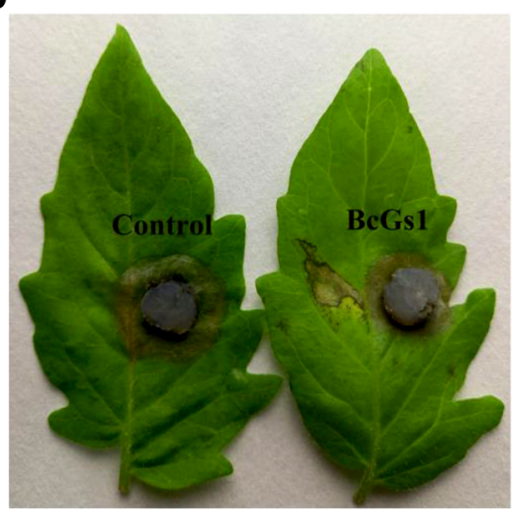

Fig. 1 BcGs1-induced disease resistance against Botrytis cinerea on detached tomato leaves. a Infection area of Botrytis cinerea at different induction times post BcGs1 infiltration. Error bars represent the means \pm SD in three biological replicates. The asterisks* and ** indicate significance of $p=0.05$ and $p=0.01$, respectively. $\mathbf{b}$ Comparison of Botrytis cinerea spot diameter at $72 \mathrm{~h}$ between BcGs1 infiltration and control 

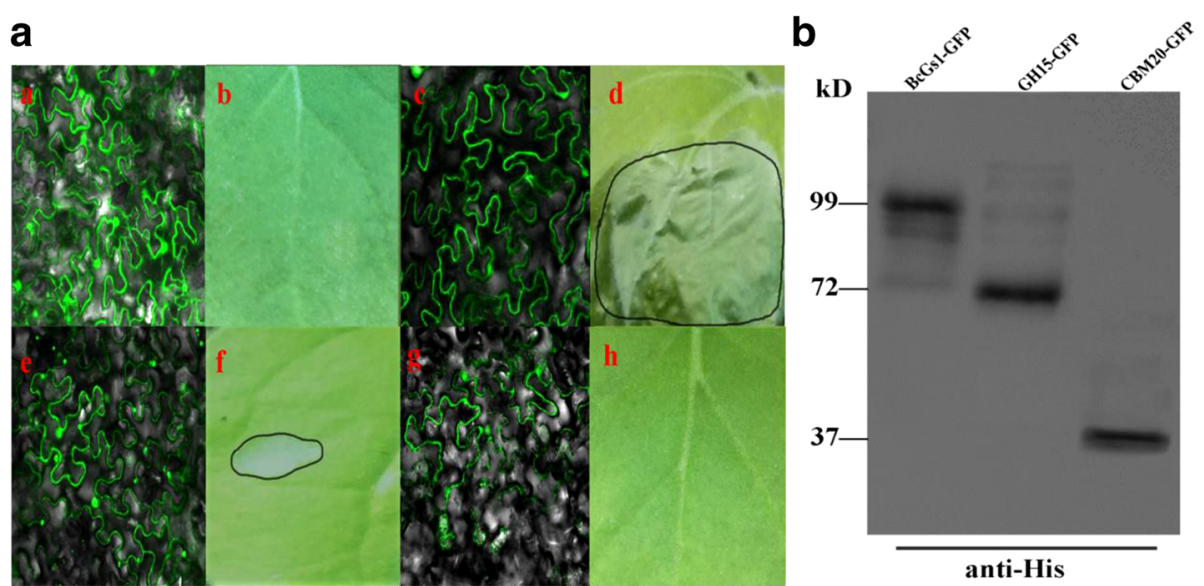

Fig. 2 Transient expression and Western Blot detection of BCGs1, GH15 and CBM20. The pYBA1152 vector was used to transiently express these proteins via Agrobacterium-mediated inoculation for $48 \mathrm{~h}$ in Nicotiana benthamiana. $\mathbf{a}$ a, $\mathrm{c}$, e and $\mathrm{g}$ represent the transient expression of the pYBA1152 empty vector, BcGs1, GH15 and CBM20; b, d, fand h represent the necrotic response induced by pYBA1152 empty vector, BcGs1, GH15 and CBM20 protein, respectively. b Western Blot verification of the expression of protein BcGs1-GFP, GH15-GFP and CBM20-GFP by His-tag

independent experiment using $\mathrm{qPCR}$. The relative expression levels of the fifteen genes are shown in Fig. 4. The genes PR1 and PR10 were up-regulated 5-8-fold at 6-12 h. The PRSTH-2-like protein was up-regulated 60 70 -fold at $6 \mathrm{~h}$, and PRSTH-2 was up-regulated $\sim 20$-fold at $12 \mathrm{~h}$. The peroxidases we tested had an up-regulation 4-10-fold between 6 and $48 \mathrm{~h}$, especially peroxidase 1 (K4D1W6), which was up-regulated 600 -fold at $24 \mathrm{~h}$. The 1,3 - $\beta$-glucanases and chitinases were up-regulated $\sim 10$ and $\sim 5$-fold at $6 \mathrm{~h}$, respectively. The auxin repressed gene was up-regulated 2.5-fold. The antifungal protein NP24 was up-regulated 3.5-fold at $6 \mathrm{~h}$. Ethylene synthesis-related protein ACC1 was up-regulated 8-fold at $6 \mathrm{~h}$. These results suggested that most genes encoding defense response proteins were up-regulated, which was consistent with the proteomics data. Up-regulation of these proteins and genes indicated that BcGs1 activated the basal defense response in tomato and induced the phenylpropane metabolic pathway.

BcGs1 activates the phenylpropanoid metabolite pathway The ROS production followed pathogen attacks as an essential component in the signal transduction cascade and mediate plant defense response [26]. We detected $\mathrm{H}_{2} \mathrm{O}_{2}$ accumulation at the inoculation site using $\mathrm{DAB}$ staining. Brown precipitates were formed in the tomato leaves at 2,4 and $6 \mathrm{~h}$ post BcGs1 infiltration (Fig. 5a). The quantitative analysis showed the $\mathrm{H}_{2} \mathrm{O}_{2}$ accumulation in BcGs1-induced tomato leaves was significantly higher than that of the control at 2, $4,6,12$ and $24 \mathrm{~h}$ post treatment and reached a maximum at $6 \mathrm{~h}$ with a 1.5 -fold increase (Fig. 5b). According to this data, we suggested that BcGs1 enhanced tomato intracellular production of $\mathrm{H}_{2} \mathrm{O}_{2}$, increased the extracellular peroxidase activities, and further generate monolignol phenoxy radicals that couple spontaneously to form lignin polymers.

The phenylpropanoid metabolite pathway is an important indicator of plant basal defense. The activities of the enzymes PAL and POD are involved in the phenylpropanoid pathway leading to the synthesis of lignin. Accordingly, PAL and POD were measured after BcGs1 infiltration (Fig. 5c). The results showed that activities of PAL and POD increased 1.5 and 2-fold compared to the untreated leaves, respectively. The data indicated that the phenylpropanoid pathway might be activated and play a defensive function in tomato.

\section{BcGs1 enhances secondary synthesis of lignin and reinforces the cell wall}

Lignin played a critical role in the plant response to pathogen infection. The synthesis and deposition of lignins were assumed to be physical barriers that made the cell walls more resistant to mechanical pressure during fungal penetration [25, 27]. BcGs1 elicitor-treated plants exhibited 1.5-fold increases in lignin deposition compared to the control at $48 \mathrm{~h}$ after elicitor treatment (Fig. 6a).

Cell wall strengthening played an important role in plant disease resistance [25]. Our results showed that the cell wall in the BcGs1-treated leaves was obviously thickened compared with the Tris- $\mathrm{HCl}$ control at 3 days and 5 days (Fig. $6 \mathrm{~b}$ ). High levels of lignin and cell wall thickness could enhance the toughness and mechanical strength of the cell wall, protect the differentiated cells, and reduce cells gap, leading to resistance to pathogen infection [22, 27]. 
Table 2 Differential function-known proteins induced by BcGs1 in tomato leaves

\begin{tabular}{|c|c|c|c|}
\hline UniprotAccession & Protein Name & Fold- change & P-Value \\
\hline B2LW68 & PR1 protein & 1.566572077 & 0.000944 \\
\hline K4CWC4 & PR10 protein & 1.462864947 & 0.014634 \\
\hline K4CWC5 & PR10 protein & 1.566549379 & 0.022764 \\
\hline $\mathrm{K} 4 \mathrm{C} 2 \mathrm{~B} 6$ & Pathogenesis-related ST-2-like protein & 3.414710726 & 0.002007 \\
\hline K4CWC6 & Pathogenesis-related STH-2 protein & 1.566676247 & 0.010109 \\
\hline Q9M3X2 & Pathogenesis-related protein (PR-5 protein) & 1.339407849 & 0.022775 \\
\hline P32045 & Pathogenesis-related protein P2 & 1.45889008 & 0.001751 \\
\hline P12670 & Protein NP24 & 1.79280756 & 0.001972 \\
\hline K4B0B4 & wound-induced protein WIN1-like & 1.569930049 & 0.001972 \\
\hline $\mathrm{K} 4 \mathrm{D} 1 \mathrm{H} 1$ & Basic endochitinase $B$ & 1.754832463 & 0.015711 \\
\hline $\mathrm{K} 4 \mathrm{D} 1 \mathrm{HO}$ & Basic endochitinase B & 1.449194796 & 0.010864 \\
\hline K4BTI7 & Endochitinase EP3 & 1.538266581 & 0.001992 \\
\hline Q7Y0S1 & Chitinase & 1.783958197 & 0.025998 \\
\hline Q43778 & Glucan endo-1,3-beta-D-glucosidase & 1.542061966 & 0.016393 \\
\hline $\mathrm{K} 4 \mathrm{CCl} 7$ & Glucan endo-1,3-beta-glucosidase 5 & 1.481474976 & 0.006155 \\
\hline Q01413 & Glucan endo-1,3-beta-glucosidase B & 1.575625293 & 0.032706 \\
\hline Q4A3Y6 & Peroxidase cevi16 & 1.346195291 & 0.00248 \\
\hline K4BD54 & Peroxidase 51 & 1.482574377 & 0.009845 \\
\hline K4BE93 & Peroxidase-2 like & 1.353913743 & 0.022862 \\
\hline K4BTH6 & Peroxidase 12 & 1.313139311 & 0.049815 \\
\hline K4C1Q9 & Peroxidase P7 & 1.49643282 & 0.005034 \\
\hline K4CQE1 & Peroxidase 21 & 1.456256379 & 0.009186 \\
\hline K4D1W6 & Peroxidase 1 & 1.545711881 & 0.005047 \\
\hline K4D6T3 & Peroxidase & 1.589423535 & 0.002984 \\
\hline K4CG47 & Proteasome subunit alpha type & 1.3264202 & 0.02516 \\
\hline K4CFM0 & Serine/threonine-protein kinase & 1.443769349 & 0.015025 \\
\hline K4ASR1 & Syntaxin-121 & 1.311591286 & 0.035885 \\
\hline D6C447 & Xanthoxin dehydrogenase & 1.751194692 & 0.000643 \\
\hline Q8RXB6 & $\begin{array}{l}\text { N-hydroxycinnamoyl-CoA: tyramine } \\
\text { N-hydroxycinnamoyl transferase THT7-8 }\end{array}$ & 1.406408234 & 0.017242 \\
\hline $\mathrm{K} 4 \mathrm{BCJ} 8$ & Patatin & 1.412470948 & 0.015274 \\
\hline K4BV09 & Patatin & 2.044321442 & 0.000288 \\
\hline H1ZXA9 & Heat shock protein 70 isoform 3 & 1.348939566 & 0.036986 \\
\hline E1AZA3 & Late embryogenesis abundant protein & 1.871127432 & 0.027053 \\
\hline K4 DC90 & Leucine aminopeptidase 1 & 1.753120542 & 0.032578 \\
\hline K4DHT1 & Dihydrolipoyl dehydrogenase & 1.42489934 & 0.001212 \\
\hline K4CYL4 & Cysteine synthase & 1.348603246 & 0.001564 \\
\hline K4BKV2 & Enolase 1, chloroplastic & 1.35345901 & 0.028962 \\
\hline $\mathrm{K} 4 \mathrm{BDC1}$ & Caffeoyl-CoA O-methyltransferase 1 & 1.876094119 & $2.25 \mathrm{E}-05$ \\
\hline K4B172 & Calreticulin-2 & 1.323221668 & 0.007139 \\
\hline P05116 & $\begin{array}{l}\text { 1-aminocyclopropane-1-carboxylate } \\
\text {-2-oxidase } 1\end{array}$ & 1.54366749 & 0.005854 \\
\hline K4B7W7 & $40 S$ ribosomal protein $\$ 25-2$ & 1.332518921 & 0.040021 \\
\hline K4BLT8 & 4-coumarate-CoA ligase 2 & 1.453093916 & 0.022281 \\
\hline K4D3M1 & $60 S$ ribosomal protein $L 4-1$ & 1.355836521 & 0.033742 \\
\hline
\end{tabular}


Table 2 Differential function-known proteins induced by BcGs1 in tomato leaves (Continued)

\begin{tabular}{|c|c|c|c|}
\hline UniprotAccession & Protein Name & Fold- change & $P$-Value \\
\hline K4BPX5 & 605 ribosomal protein $L 6-3$ & 1.321870467 & 0.031334 \\
\hline K4BXJ9 & $\begin{array}{l}\text { 6-phosphogluconate dehydrogenase, } \\
\text { decarboxylating } 3\end{array}$ & 1.377879577 & 0.022689 \\
\hline K4C740 & Alanine aminotransferase 1, mitochondrial & 1.406412755 & 0.011761 \\
\hline K4D7Q7 & 12-oxophytodienoate reductase 1 & 0.654045863 & 0.001084 \\
\hline K4BWB5 & 30 S ribosomal protein S13, chloroplastic & 0.76212412 & 0.000918 \\
\hline Q2MI78 & 30 S ribosomal protein S18, chloroplastic & 0.735498477 & 0.003657 \\
\hline Q2QJT5 & ASR4 & 0.487069561 & 0.006403 \\
\hline Q0PY39 & $\begin{array}{l}\text { Auxin repressed/dormancy associated } \\
\text { protein }\end{array}$ & 0.573787795 & 0.000427 \\
\hline K4CV63 & Cytochrome b-c1 complex subunit 6 & 0.699897597 & 0.029526 \\
\hline Q5NE20 & Carbonic anhydrase & 0.693825962 & 0.049301 \\
\hline K4D9P5 & DNA ligase & 0.661355604 & 0.022205 \\
\hline G8D593 & $\begin{array}{l}\text { Ribulose bisphosphate carboxylase large } \\
\text { chain (Fragment) }\end{array}$ & 0.610547859 & 0.030248 \\
\hline P27065 & $\begin{array}{l}\text { Ribulose bisphosphate carboxylase large } \\
\text { chain }\end{array}$ & 0.695991889 & 0.042018 \\
\hline P08706 & $\begin{array}{l}\text { Ribulose bisphosphate carboxylase small } \\
\text { chain 1, chloroplastic }\end{array}$ & 0.72863624 & 0.025037 \\
\hline P05349 & $\begin{array}{l}\text { Ribulose bisphosphate carboxylase small } \\
\text { chain } 3 B \text {, chloroplastic }\end{array}$ & 0.701040127 & 0.005291 \\
\hline Q3C2L6 & Sorbitol related enzyme & 0.703582864 & 0.005221 \\
\hline K4CIE2 & Peptidyl-prolyl cis-trans isomerase & 0.76180139 & 0.019223 \\
\hline K4CAM3 & $\begin{array}{l}\text { Photosystem I reaction center subunit IV } \\
\text { B, chloroplastic }\end{array}$ & 0.766668988 & 0.008467 \\
\hline K4CJ02 & $\begin{array}{l}\text { Photosystem I reaction center subunit N, } \\
\text { chloroplastic }\end{array}$ & 0.664262723 & 0.047516 \\
\hline Q40163 & $\begin{array}{l}\text { Photosystem II } 10 \mathrm{kDa} \text { polypeptide, } \\
\text { chloroplastic }\end{array}$ & 0.684317387 & 0.028599 \\
\hline V5YNW6 & Plasma membrane intrinsic protein 21 & 0.672034247 & 0.003512 \\
\hline K4BIT3 & Polyadenylate-binding protein 1 & 0.732236793 & 0.005001 \\
\hline K4D305 & $\begin{array}{l}\text { Glycine-rich RNA-binding protein 3, } \\
\text { mitochondrial }\end{array}$ & 0.768783343 & 0.002869 \\
\hline
\end{tabular}

\section{Discussion}

Successful pathogen infection must break physical barriers and chemical defenses in plants. Plant cell walls are an important barrier against pathogen attack regardless of the biotrophic and necrotrophic pathogens. To overcome plant defense, the pathogen secretes various types of CWDEs to degrade the plant cell wall. CWDEs are conserved in extensive pathogens and recognized as PAMPs or DAMPs to initiate PTI. BcGs1, a CWDE secreted from Botrytis cinerea, could induce the defense response and improve disease resistance to Botrytis cinerea in tomato [23]. However, the mechanism is unclear. To investigate the difference in the defense response of BcGs1 treated plants and control plants, proteomics was applied to analyze the differential proteins. Forty-six up-regulated and 20 down-regulated proteins were detected. PR proteins, chitinases, peroxidases, 1 , 3 - $\beta$-glucanases and secondary metabolic related proteins were enriched based on Go analysis and KEGG analysis.

Pathogenesis-related (PR) proteins have been used as biomarkers of plant defense responses [28] and have been distinguished entities for system acquired resistance (SAR) in plants [29]. Based on the PRs functional properties and structure, 17 different PR protein families have been characterized, and these PR families have a wide range of functions from making the cell wall more rigid to signal transduction and antimicrobial activity [30]. In our present study, 16 PR proteins, including PR1, PR5, PRP2, PR10, PRSTH-2/PRSTH-2-like proteins, chitinases and glucan $1,3-\beta$-glucosidases, were significantly induced in BcGs1-treated tomato leaves. PR1 proteins have antifungal activity in tomatoes and 


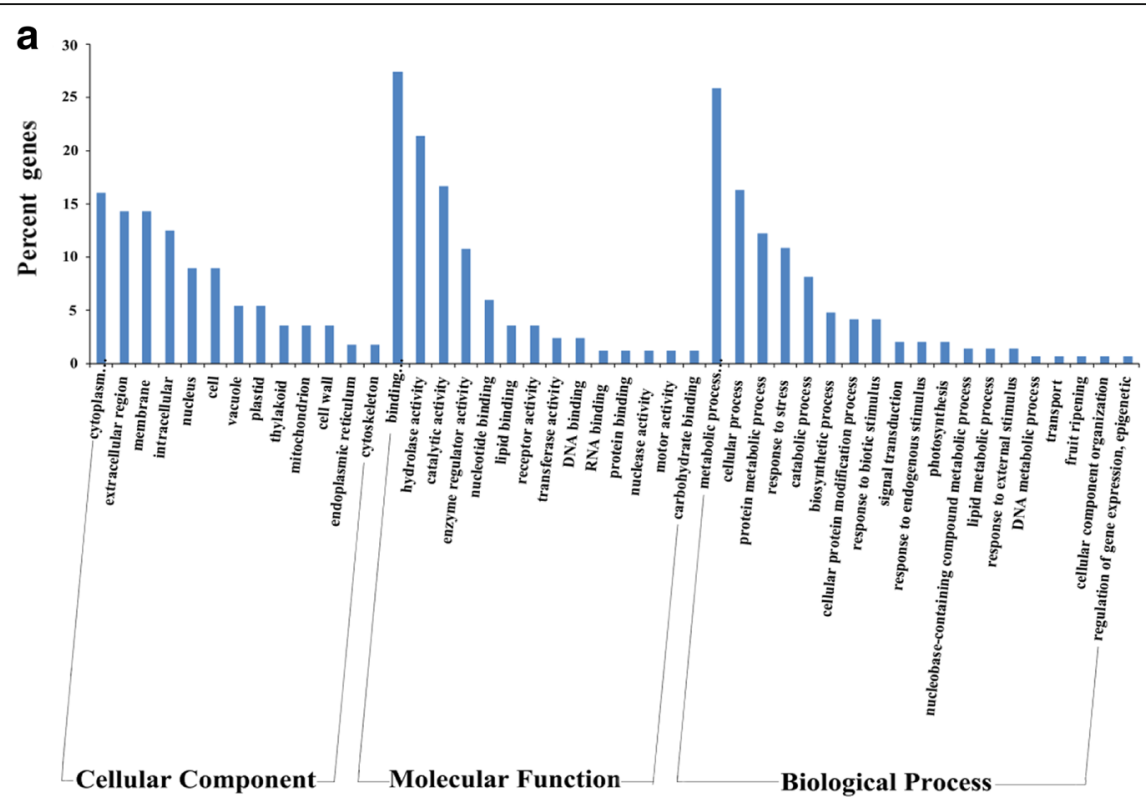

b

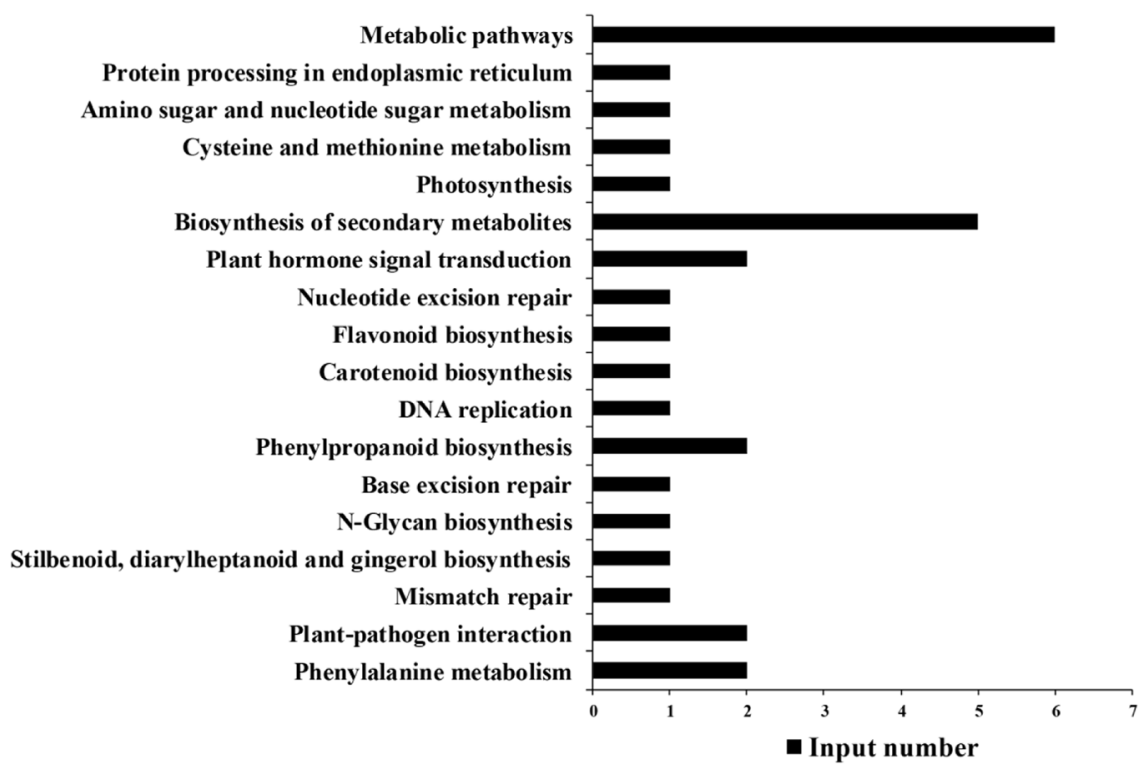

Fig. 3 Analysis of the GO function enrichment and KEGG pathway of the differential proteins. a Percent of differentially expressed proteins in the cellular components, molecular functions and biological processes; $\mathbf{b}$ The KEGG pathway enrichment analysis of differential proteins

tobacco, but the mechanism remain unknown [31]. PR5 proteins include thaumatin, osmotin and related proteins, many of which also have antimicrobial activity [32]. The PRP2 protein, a member of the proline-rich protein family, was a structural cell wall protein and accumulated in response to fungal pathogen attack and Phytophthora megasperma f. sp. glycinea elicitors [33, 34]. $\mathrm{H}_{2} \mathrm{O}_{2}$ mediated the oxidative cross-linking of the PRP2 protein into the wall structure. Moreover, the PRP2 protein also regulated cell wall properties and was involved in development and defense [35]. PRSTH-2, belonging to the PR-10 family, was regulated by fungal elicitors, plant hormones and defense-related signaling molecules [30,36]. Chitinases were released in the early stage of pathogen infection and could hydrolyze fungal cell wall chitin, when hyphae penetrated the intercellular space, to inhibit its growth [37]. Glucan 1, 3 - $\beta$-glucosidases belong to PR-2 protein family, with a function to hydrolyze $\beta-1,3$-glucans, which are major structural compounds of fungal cell walls [38]. Increased expression of PR protein information indicated that BcGs1 induced the tomato basal defense, including cell wall reinforcement, biosynthesis of antimicrobial phytoalexin and phytohormone. 


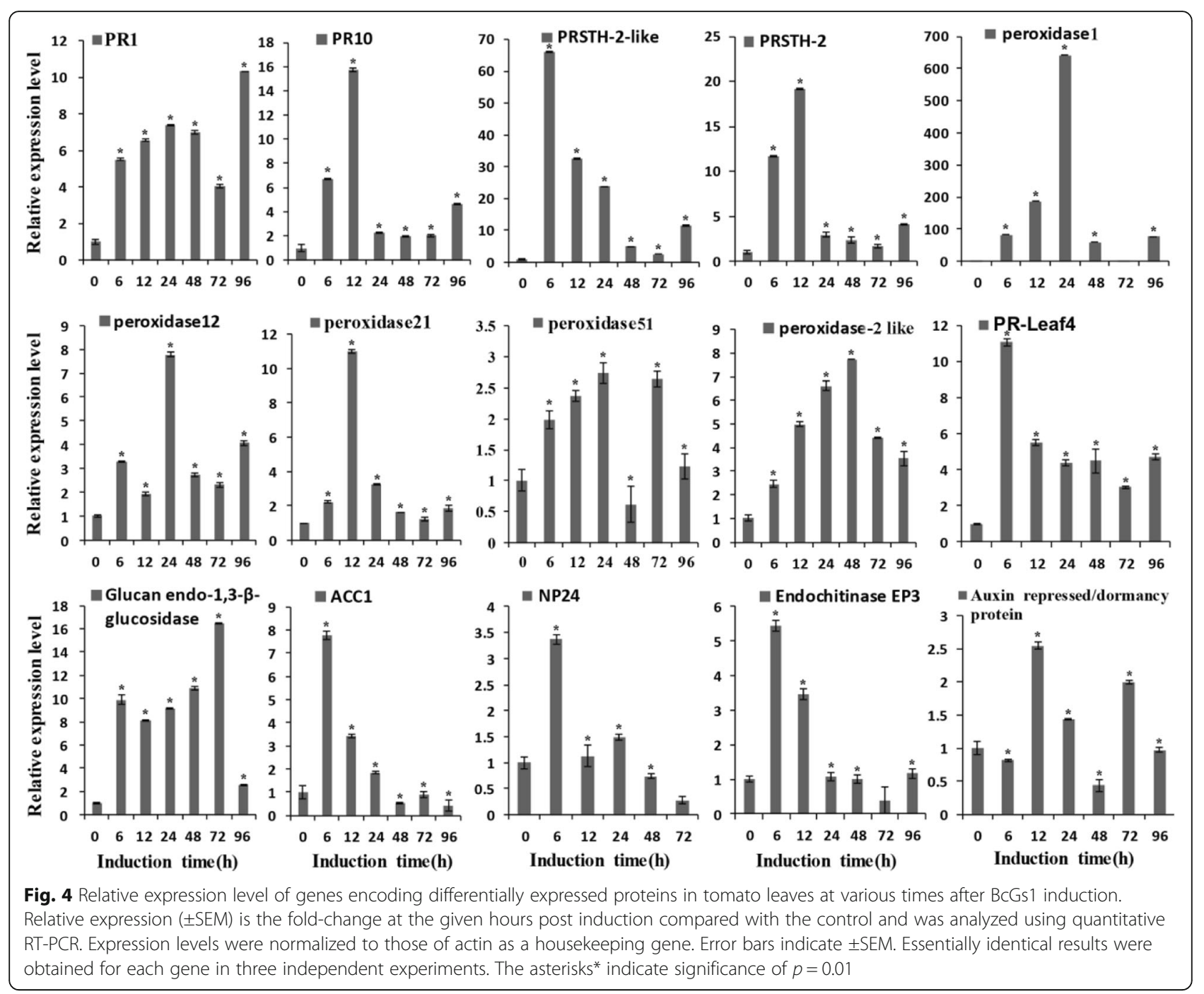

Peroxidase was divided into two types: class I and class III; class I is intracellular, while class III is secreted into the cell wall or the surrounding medium [39]. Class III comprises the secretory plant peroxidases, which have multiple tissue-specific functions, such as the removal of hydrogen peroxide from chloroplasts and cytosol, biosynthesis of the cell wall, and wounding defense responses [40]. In our experiment, eight differential expression peroxidases were detected, including peroxidase (K4D6T3), peroxidase1, peroxidase12, peroxidase21, peroxidase cevi16, peroxidase- 2 like, peroxidaseP7, and peroxidase 51, and they all belong to class III. Peroxidases can prevent excessive accumulation of $\mathrm{H}_{2} \mathrm{O}_{2}$, remove $\mathrm{H}_{2} \mathrm{O}_{2}$ and mediate many $\mathrm{H}_{2} \mathrm{O}_{2}$-related defense responses [26]. Peroxidases are also involved in phenolic metabolism and biosynthesis of lignin from cinnamyl alcohols and other polymers [41-43]. Overexpression of a basic peroxidase in transgenic tomato plants exhibited a higher lignin content than the wild-type plants
[44, 45]. Individual Arabidopsis peroxidase (AtPrx) gene families are also involved in both cell growth and lignification in a variety of tissue types, including stems, leaves, and roots [46-49]. The defensive action of peroxidases is probably accompanied by the activation of other defense enzymes, such as $\beta-1,3$-glucanase and chitinases [39]. Although the function of peroxidase is ambiguous, the role of peroxidases in the detoxification of ROS and lignification, as well as the efficient coupling of the two processes, was acknowledged [44]. Therefore, our results demonstrated that the accumulation of peroxidases decreased the cell-wall plasticity by the lignification of the cell in the response to BcGs1 stress.

ROS production was one of the earliest defense responses against pathogen invasion in plant-pathogen interactions [50, 51]. $\mathrm{H}_{2} \mathrm{O}_{2}$ accumulation at the site of pathogen infection has been shown to be decisive for the outcome of tomato-pathogen interactions [52]. It could cause direct pathogen destruction, trigger hypersensitive 


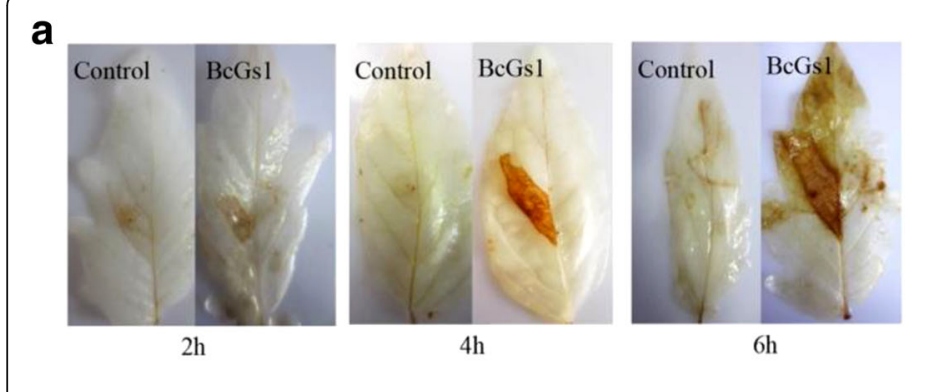

b

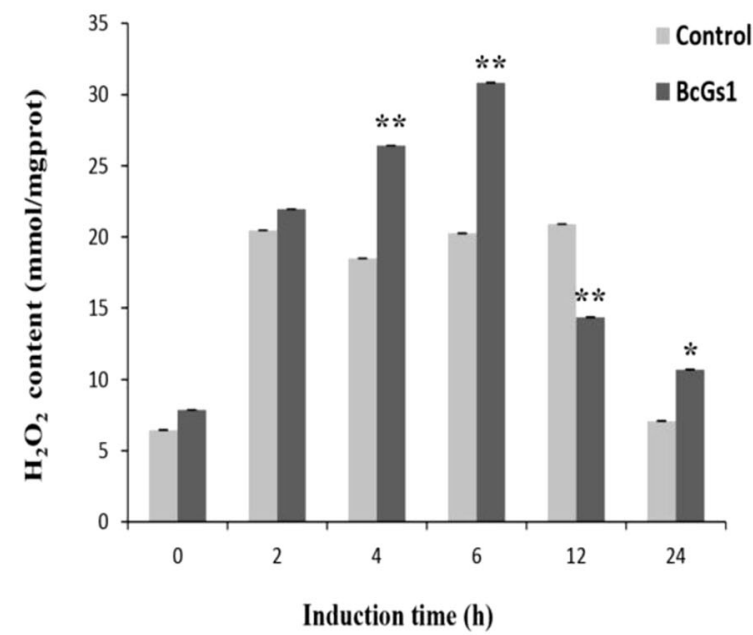

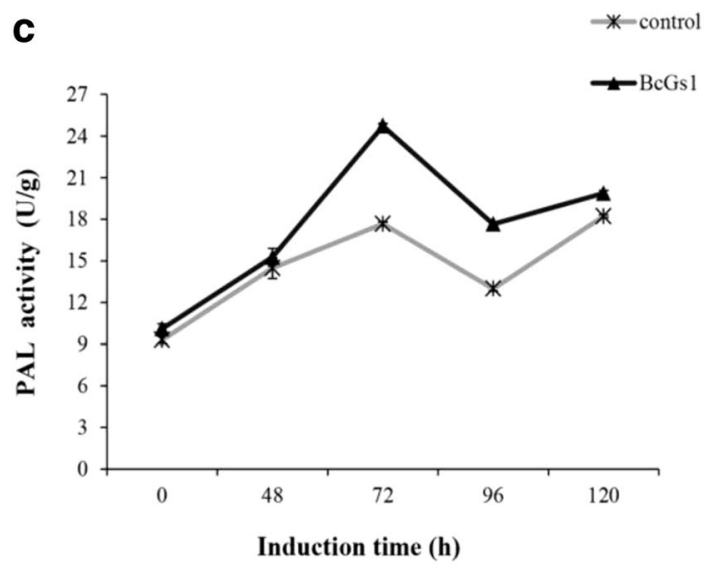

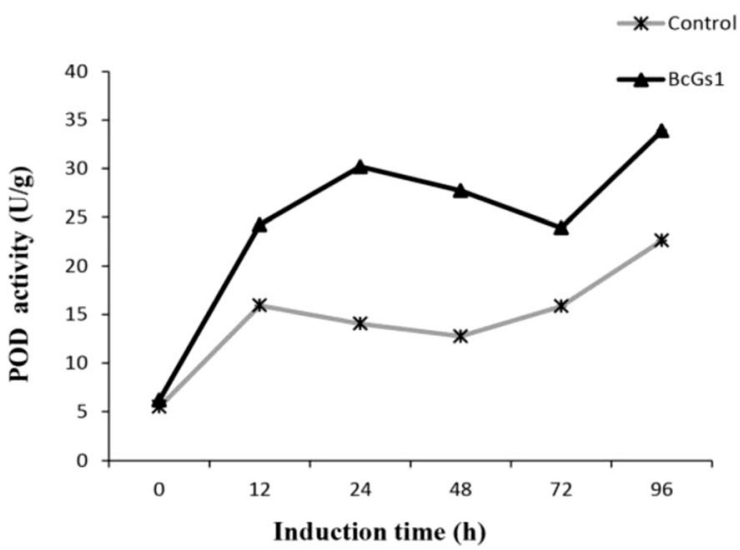

Fig. $5 \mathrm{H}_{2} \mathrm{O}_{2}$ accumulation and the activity of PAL and POD in BcGs1-induced tomato leaves. a $\mathrm{H}_{2} \mathrm{O}_{2}$ accumulation at $2 \mathrm{~h}, 4 \mathrm{~h}, 6 \mathrm{~h}$ after BcGs1 induction; $\mathbf{b}$ Quantitative determination of $\mathrm{H}_{2} \mathrm{O}_{2}$ content. BcGs1-infiltrated areas were stained brown compared with the buffer control. The asterisks* and ** indicate significance of $p=0.05$ and $p=0.01$, respectively. $\mathbf{c}$ Kinetics of PAL and POD activity after BcGs1 treatment of the leaves. The activities were measured $0-120 \mathrm{~h}$ after BcGs1 treatment. The values are the mean \pm SD of triplicate samples

cell death, activate defense response-related genes, or serve as a secondary messenger in the systemic signaling network of the plant cell [50,53-55]. Furthermore, $\mathrm{H}_{2} \mathrm{O}_{2}$ was also found to be critical for determining the resistance of tomato to Cladosporium fulvum, anthracnose fungus and powdery mildew fungus [56-58]. $\mathrm{H}_{2} \mathrm{O}_{2}$ accumulation in the epidermal cell layer was accompanied by an increase in the extracellular peroxidase activities, and the peroxidases mediated many $\mathrm{H}_{2} \mathrm{O}_{2}$-related defense responses and caused cell wall modification [26]. A severe accumulation of $\mathrm{H}_{2} \mathrm{O}_{2}$ was observed in BcGs1-treated tomato leaves at $24 \mathrm{~h}$ and increased 1.5 -fold at $6 \mathrm{~h}$. Moreover, lignin accumulated after $6 \mathrm{~h}$ of treatment by BcGs1. These results showed that $\mathrm{BcGs} 1$ activated $\mathrm{H}_{2} \mathrm{O}_{2}$-related defense responses, resulting in lignin accumulation.

\section{Biosynthesis of secondary metabolites related proteins}

Secondary metabolites play a fundamental role in the plant's fight against pathogen infection. Based on the biosynthesis substrates and pathways, phenylpropanoid, nitrogen-containing substances and terpenoid pathways were classified [59]. Terpenoid and quinone compounds could enhance plant disease resistance. Multiple branches of the phenylpropanoid pathway have been reported for various model plants, including tomato, rice, Arabidopsis and legume plants [60-62]. Many phenylpropanoids exhibit broad-spectrum antimicrobial activity and help the plant fight microbial disease. In our study, the key protein 4-coumarate-CoA ligase 2 (4CL) and Caffeoyl-CoA O-methyltransferase 1 (CCoAMT1) synthesize the G-lignin monomer in the branch where the phenylpropanoid pathway was identified. Previous results found that CCoAMT down regulation in alfalfa resulted in the reduction of $G$ lignin units [63]. The two essential proteins and encoding genes were significantly up-regulated post-BcGs1 infiltration, indicating that BcGs1 activates the phenylpropanoid pathway in the tomato.

\section{Lignin formation and cell wall histochemical localization}

Lignin, a major component of the secondary cell wall of plants, is an important part of the defense against the penetration of invading pathogens [64-66]. Lignin can enhance the mechanical strength, alter the compressibility and porosity of the cell wall and form a barrier 

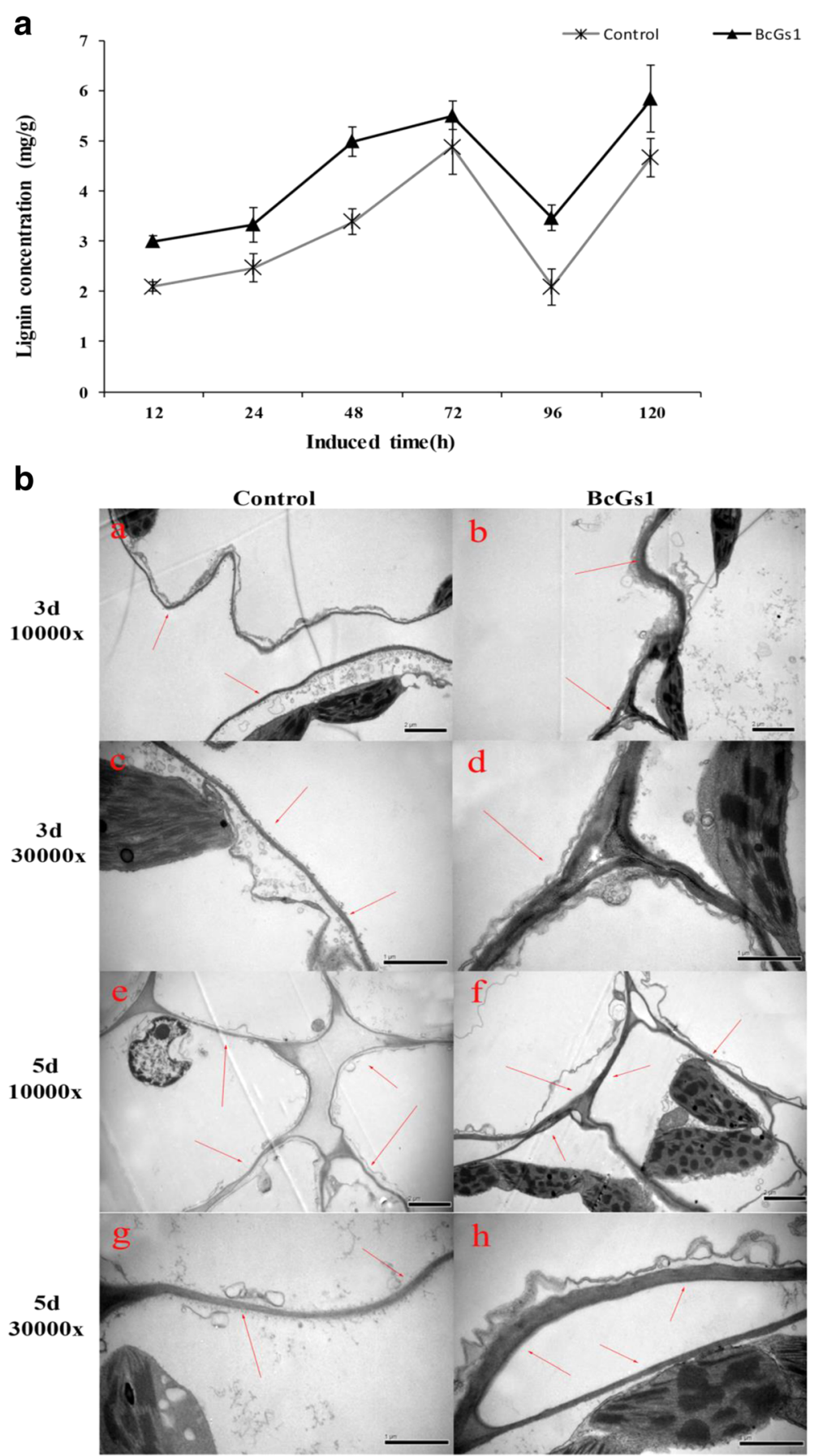

Fig. 6 Lignin accumulation and cell wall thickening induced by BcGs1 in tomato leaves. a Lignin accumulation was measured at 12, 24, 48, 72, 96 and $120 \mathrm{~h}$, and the data are the mean \pm SD from three independent experiments. $\mathbf{b}$ Electron microscopy observation of the cell wall in the BcGs1-treated tomato leaf and control. a, b, e, and f were observed at 10000x; c, d g, and h were observed at 30000x. a and c, e and g were the control at 3 days and 5 days, respectively; $b$ and $d, f$ and $h$ were treated by BcGs 1 at $3 d$ and $5 d$, respectively. Red arrows point to the cell wall

against the infection of pathogens [64, 67-69]. In the present study, differences in lignin content between BcGs1-treatment and Tris-HCl buffer-treated leaves were analyzed, and the results showed that the lignin content in BcGs1-treated leaves exhibited a 1.5-fold increase compared to the control, indicating that it might restrict Botrytis cinerea spread in tomato. Moreover, the key enzymes involved in this pathway, such as PAL, POD, 4CL and CCoAMT1, were detected after BcGs1 was induced in tomato leaves. These observations 
were confirmed via the transcriptionally up-regulated expression of the PAL, POD 4CL and CCoAMT1 genes compared to the control. Furthermore, histochemical localization showed that the cell wall of BcGs1-treated leaves was significantly thickened post BcGs1 treatment compared to the control. Cell wall thickening enhanced the mechanical strength and improved disease resistance to Botrytis cinerea infection.

\section{Conclusions}

BcGs1 could significantly activate disease resistance against Botrytis cinerea at $72 \mathrm{~h}$ post-induction. Two domains are required for BcGs1 full necrosis activity. Differential expression proteins were identified in tomato plants using a proteomics approach. PR proteins, peroxidases, Glucan endo-1, 3- $\beta$-glucosidase, chitinases, ethylene synthesis-related proteins, and biosynthesis of secondary metabolites were involved in BcGs1-induced resistance. BcGs1-infiltrated tomato plants exhibited $\mathrm{H}_{2} \mathrm{O}_{2}$ accumulation, increased levels of regulation of the key PAL and POD enzymes, lignin end-product accumulation in the phenylpropanoid pathway, and cell wall thickening. According to BcGs1-induced PR differential expression proteins, peroxidase and the biosynthesis of secondary metabolites, the mechanisms by which BcGs1 triggers disease resistance against Botrytis cinerea were summarized as follows. BcGs1 induced $\mathrm{H}_{2} \mathrm{O}_{2}$ production, which not only increased peroxidase activity but also caused cell wall strengthening and lignin accumulation. Meanwhile, many defense-related proteins were up-regulated, including PRs, Glucan endo-1, 3 - $\beta$-glucosidase and chitinase. By combining biochemical and histochemical data, we suggested that BcGs1 triggers up-regulation of the phenylpropanoid pathway-related genes and protein, enzyme activities, high lignin levels and cell wall thickness, and ultimately generates tomato disease resistance. Overall, lignin metabolism played a critical role and was involved in BcGs1-induced defense response in the tomato.

\section{Additional file}

Additional file 1: Figure S1. Purification and necrosis activity of the protein BcGs1. A: SDS-PAGE analysis of purified BcGs1. M, Protein marker. 1, Purified BcGs1. B: Necrosis activity of BcGs1 in tomato, tobacco, cucumber and pea leaves. (DOCX $673 \mathrm{~kb})$

\section{Abbreviations}

4CL: 4-coumarate-CoA ligase 2; CCoAMT1: Caffeoyl-CoA O-methyltransferase 1; CWDE: cell wall-degrading enzyme; DAB: nitro 3, 3'-diaminobenzidine; PAL: phenylalanine-ammonia lyase; PAMP: pathogen-associated molecular patterns; POD: peroxidase; PR: pathogenesis-related proteins; PTI: microbeassociated molecular pattern (MAMP)-triggered immunity; ROS: reactive oxygen species; TGA: thioglycolic acid

\section{Funding}

This research was supported by the National Key Research and Development Program of China (2017YFD0201100). The funding body did not play any roles in the design of the study and collection, analysis, and interpretation of data and in writing the manuscript.

\section{Availability of data and materials}

All data generated or analysed during this study are included in this published article and its supplementary information files.

\section{Authors' contributions}

$X Y, D Q, H Z$ and $J Y$ designed and guidanced the experiments. $C Y$ and $Y L$ analyzed the date of Proteomics. YL collected the samples. CY and XY performed the experiments and drafted the manuscript with the contribution of all authors. All authors read and approved the final manuscript.

\section{Ethics approval and consent to participate}

Tomato (Solanum lycopersicum L.) seeds "zhongza9hao", obtained the permission of Ministry of Agriculture of the People's Republic of China, were purchased from Institute of Vegetables and Flowers, Chinese Academy of Agricultural Sciences.

The phytosanitary certificate number is 620,900,200,000,857.

\section{Competing interests}

The authors declare that they have no competing interests.

\section{Publisher's Note}

Springer Nature remains neutral with regard to jurisdictional claims in published maps and institutional affiliations.

Received: 30 September 2017 Accepted: 24 May 2018

Published online: 04 June 2018

References

1. Eder J, Cosio EG. Elicitors of plant defense responses. Int Rev Cytol. 1994; 148:1-36.

2. Jones JD, Dangl JL. The plant immune system. Nature. 2006;444(7117):323.

3. Pieterse CM, Schaller A, Mauch-Mani B, Conrath U. Signaling in plant resistance responses: divergence and cross-talk of defense pathways. In: Multigenic and induced systemic resistance in plants. Boston: Springer; 2006;166-96.

4. Zipfel C. Early molecular events in PAMP-triggered immunity. Curr Opin Plant Biol. 2009;12(4):414-20.

5. Blumwald E, Aharon GS, Lam BC. Early signal transduction pathways in plant-pathogen interactions. Trends Plant Sci. 1998;3(9):342-6.

6. Nürnberger T, Scheel D. Signal transmission in the plant immune response. Trends Plant Sci. 2001;6(8):372-9.

7. Fritig B, Heitz T, Legrand M. Antimicrobial proteins in induced plant defense. Curr Opin Immunol. 1998;10(1):16-22.

8. Somssich IE, Hahlbrock K. Pathogen defence in plants - a paradigm of biological complexity. Trends Plant Sci. 1998;3(3):86-90.

9. Williamson B, Tudzynski B, Tudzynski P, van Kan JA. Botrytis cinerea: the cause of grey mould disease. Mol Plant Pathol. 2007;8(5):561-80.

10. Mengiste T. Plant immunity to necrotrophs. Annu Rev Phytopathol. 2012;50:267-94

11. Elad $Y$, Williamson B, Tudzynski P, Delen N. Botrytis spp. and diseases they cause in agriculturalsystems-an introduction. Botrytis: Biology, pathology and control. Dordrecht: Springer; 2007:1-8.

12. van Kan JA. Licensed to kill: the lifestyle of a necrotrophic plant pathogen. Trends Plant Sci. 2006:11(5):247-53.

13. Repka V. Early defence responses induced by two distinct elicitors derived from a Botrytis cinerea in grapevine leaves and cell suspensions. Biol Plant. 2006;50(1):94-106.

14. Poinssot B, Vandelle E, Bentéjac M, Adrian M, Levis C, Brygoo Y, Garin J, Sicilia F, Coutos-Thévenot P, Pugin A. The endopolygalacturonase 1 from Botrytis cinerea activates grapevine defense reactions unrelated to its enzymatic activity. Mol Plant-Microbe Interact. 2003;16(6):553-64.

15. Brutus A, Sicilia F, Macone A, Cervone F, De Lorenzo G. A domain swap approach reveals a role of the plant wall-associated kinase 1 (WAK1) as a receptor of oligogalacturonides. Proc Natl Acad Sci. 2010;107(20):9452-7.

16. Ferrari S, Galletti R, Denoux C, De Lorenzo G, Ausubel FM, Dewdney J. Resistance to Botrytis cinerea induced in Arabidopsis by elicitors is 
independent of salicylic acid, ethylene, or jasmonate signaling but requires PHYTOALEXIN DEFICIENT3. Plant Physiol. 2007;144(1):367-79.

17. Noda J, Brito N, González C. The Botrytis cinerea xylanase Xyn11A contributes to virulence with its necrotizing activity, not with its catalytic activity. BMC Plant Biol. 2010;10(1):38.

18. Denoux C, Galletti R, Mammarella N, Gopalan S, Werck D, De Lorenzo G, Ferrari S, Ausubel FM, Dewdney J. Activation of defense response pathways by OGs and Flg22 elicitors in Arabidopsis seedlings. Mol Plant. 2008;1(3):423-45.

19. Galletti R, Denoux C, Gambetta S, Dewdney J, Ausubel FM, De Lorenzo G, Ferrari S. The AtrbohD-mediated oxidative burst elicited by oligogalacturonides in Arabidopsis is dispensable for the activation of defense responses effective against Botrytis cinerea. Plant Physiol. 2008; 148(3):1695-706.

20. Mengiste T, Laluk K, AbuQamar S. Mechanisms of induced resistance against B. Cinerea. In: Prusky D, Gullino ML, editors. Postharvest pathology. Dordrecht: Springer Netherlands; 2010. p. 13-30

21. Khan NU, Liu M, Yang X, Qiu D. Fungal elicitor MoHrip2 induces disease resistance in Rice leaves, triggering stress-related pathways. PLoS One. 2016;11(6):e0158112.

22. Xu L, Zhu L, Tu L, Liu L, Yuan D, Jin L, Long L, Zhang X. Lignin metabolism has a central role in the resistance of cotton to the wilt fungus Verticillium dahliae as revealed by RNA-Seq-dependent transcriptional analysis and histochemistry. J Exp Bot. 2011;62(15):5607-21.

23. Zhang $Y$, Zhang $Y$, Qiu D, Zeng H, Guo L, Yang X. BcGs 1, a glycoprotein from Botrytis cinerea, elicits defence response and improves disease resistance in host plants. Biochem Biophys Res Commun. 2015;457(4):627-34.

24. Eudes A, Pollet B, Sibout R, Do C-T, Séguin A, Lapierre C, Jouanin L. Evidence for a role of AtCAD 1 in lignification of elongating stems of Arabidopsis thaliana. Planta. 2006;225(1):23-39.

25. Bu B, Qiu D, Zeng H, Guo L, Yuan J, Yang X. A fungal protein elicitor PevD1 induces Verticillium wilt resistance in cotton. Plant Cell Rep. 2014;33(3):461-70.

26. Asselbergh B, Curvers K, França SC, Audenaert K, Vuylsteke M, Van Breusegem F, Höfte M. Resistance to Botrytis cinerea in sitiens, an abscisic acid-deficient tomato mutant, involves timely production of hydrogen peroxide and cell wall modifications in the epidermis. Plant Physiol. 2007;144(4):1863-77.

27. Smit F, Dubery IA. Cell wall reinforcement in cotton hypocotyls in response to a Verticillium dahliae elicitor. Phytochemistry. 1997:44(5):811-5.

28. Mitsuhara I, Iwai T, Seo S, Yanagawa Y, Kawahigasi H, Hirose S, Ohkawa Y, Ohashi Y. Characteristic expression of twelve rice PR1 family genes in response to pathogen infection, wounding, and defense-related signal compounds (121/180). Mol Gen Genomics. 2008;279(4):415-27.

29. Prins TW, Tudzynski P, von Tiedemann A, Tudzynski B, Ten Have A, Hansen ME, Tenberge $K$, van KanJA. Infection strategies of Botrytis cinerea and related necrotrophic pathogens. Fungal Pathology. Netherlands: Springer; 2000:33-64.

30. Liu J-J, Ekramoddoullah AK. The family 10 of plant pathogenesis-related proteins: their structure, regulation, and function in response to biotic and abiotic stresses. Physiol Mol Plant Pathol. 2006;68(1):3-13.

31. Lu S, Friesen TL, Faris JD. Molecular characterization and genomic mapping of the pathogenesis-related protein 1 (PR-1) gene family in hexaploid wheat (Triticum aestivum L.). Mol Gen Genomics. 2011;285(6):485.

32. Shatters RG, Boykin LM, Lapointe SL, Hunter WB, Weathersbee A. Phylogenetic and structural relationships of the PR5 gene family reveal an ancient multigene family conserved in plants and select animal taxa. J Mol Evol. 2006;63(1):12-29.

33. Bradley DJ, Kjellbom P, Lamb CJ. Elicitor-and wound-induced oxidative cross-linking of a proline-rich plant cell wall protein: a novel, rapid defense response. Cell. 1992;70(1):21-30.

34. McKenzie C, Shatters RG, Doostdar H, Lee S, Inbar M, Mayer RT. Effect of geminivirus infection and Bemisia infestation on accumulation of pathogenesisrelated proteins in tomato. Arch Insect Biochem Physiol. 2002;49(4):203-14.

35. Keller B. Structural cell wall proteins. Plant Physiol. 1993;101(4):1127.

36. Van Loon L, Van Strien E. The families of pathogenesis-related proteins, their activities, and comparative analysis of PR-1 type proteins. Physiol Mol Plant Pathol. 1999;55(2):85-97.

37. Kasprzewska A. Plant chitinases-regulation and function. Cell Mol Biol Lett. 2003;8(3):809-24

38. Floerl S, Majcherczyk A, Possienke M, Feussner K, Tappe H, Gatz C, Feussner I, Kües U, Polle A. Verticillium longisporum infection affects the leaf apoplastic proteome, metabolome, and cell wall properties in Arabidopsis thaliana. PLoS One. 2012;7(2):e31435.
39. Passardi F, Penel C, Dunand C. Performing the paradoxical: how plant peroxidases modify the cell wall. Trends Plant Sci. 2004;9(11):534-40.

40. Hiraga S, Sasaki K, Ito H, Ohashi Y, Matsui H. A large family of class III plant peroxidases. Plant Cell Physiol. 2001;42(5):462-8.

41. Barceló AR. Lignification in plant cell walls. Int Rev Cytol. 1997;176:87-132.

42. Blee KA, Choi JW, O'Connell AP, Schuch W, Lewis NG, Bolwell GP. A ligninspecific peroxidase in tobacco whose antisense suppression leads to vascular tissue modification. Phytochemistry. 2003;64(1):163-76.

43. Li Y, Kajita S, Kawai S, Katayama Y, Morohoshi N. Down-regulation of an anionic peroxidase in transgenic aspen and its effect on lignin characteristics. J Plant Res. 2003;116(3):175-82.

44. Díaz J, Bernal A, Pomar F, Merino F. Induction of shikimate dehydrogenase and peroxidase in pepper (Capsicum annuum L.) seedlings in response to copper stress and its relation to lignification. Plant Sci. 2001;161(1):179-88.

45. El Mansouri I, Mercado JA, Santiago-Dómenech N, Pliego-Alfaro F, Valpuesta $\checkmark$, Quesada MA. Biochemical and phenotypical characterization of transgenic tomato plants overexpressing a basic peroxidase. Physiol Plant. 1999;106(4):355-62.

46. Fraser CM, Chapple C. The phenylpropanoid pathway in Arabidopsis. The Arabidopsis Book. 2011;9(e0152):e0152.

47. Tognolli M, Penel C, Greppin H, Simon P. Analysis and expression of the class III peroxidase large gene family in Arabidopsis thaliana. Gene. 2002; 288(1):129-38.

48. Valerio P, Pereira MM, Goes AM, Leite MF. The effect of ionic products from bioactive glass dissolution on osteoblast proliferation and collagen production. Biomaterials. 2004;25(15):2941-8.

49. Welinder KG, Justesen AF, Kjærsgård IV, Jensen RB, Rasmussen SK, Jespersen HM, Duroux L. Structural diversity and transcription of class III peroxidases from Arabidopsis thaliana. FEBS J. 2002;269(24):6063-81.

50. Apel K, Hirt H. Reactive oxygen species: metabolism, oxidative stress, and signal transduction. Annu Rev Plant Biol. 2004;55:373-99.

51. Lamb C, Dixon RA. The oxidative burst in plant disease resistance. Annu Rev Plant Biol. 1997;48(1):251-75.

52. Khatun S, Cakilcioglu U, Chakrabarti M, Ojha S, Chatterjee NC. Biochemical defense against die-back disease of a traditional medicinal plant Mimusops elengi Linn. Eur J Med Plant. 2011;2(2).

53. Bestwick CS, Brown IR, Mansfield JW. Localized changes in peroxidase activity accompany hydrogen peroxide generation during the development of a nonhost hypersensitive reaction in lettuce. Plant Physiol. 1998; 1 18(3):1067-78.

54. Levine A, Tenhaken R, Dixon R, Lamb C. H 2 O 2 from the oxidative burst orchestrates the plant hypersensitive disease resistance response. Cell. 1994;79(4):583-93.

55. Shetty NP, Kristensen B, Newman M-A, Møller K, Gregersen PL, Jørgensen $\mathrm{HL}$. Association of hydrogen peroxide with restriction of Septoria tritici in resistant wheat. Physiol Mol Plant Pathol. 2003;62(6):333-46.

56. Borden S, Higgins VJ. Hydrogen peroxide plays a critical role in the defence response of tomato to Cladosporium fulvum. Physiol Mol Plant Pathol. 2002;61(4):227-36.

57. Mellersh DG, Foulds IV, Higgins VJ, Heath MC. H2O2 plays different roles in determining penetration failure in three diverse plant-fungal interactions. Plant J. 2002;29(3):257-68.

58. Mlíčková K, Luhová L, Lebeda A, Mieslerová B, Peč P. Reactive oxygen species generation and peroxidase activity during Oidium neolycopersici infection on Lycopersicon species. Plant Physiol Biochem. 2004;42(10):753-61.

59. Makkar $\mathrm{H}$, Francis $\mathrm{G}$, Becker K. Bioactivity of phytochemicals in some lesserknown plants and their effects and potential applications in livestock and aquaculture production systems. animal. 2007:1 (9):1371-91.

60. Azaiez A, Boyle B, Levée V, Séguin A. Transcriptome profiling in hybrid poplar following interactions with Melampsora rust fungi. Mol PlantMicrobe Interact. 2009;22(2):190-200.

61. Uppalapati SR, Marek SM, Lee H-K, Nakashima J, Tang Y, Sledge MK, Dixon RA, Mysore KS. Global gene expression profiling during Medicago truncatula-Phymatotrichopsis omnivora interaction reveals a role for jasmonic acid, ethylene, and the flavonoid pathway in disease development. Mol Plant-Microbe Interact. 2009;22(1):7-17.

62. Zabala G, Zou J, Tuteja J, Gonzalez DO, Clough SJ, Vodkin LO. Transcriptome changes in the phenylpropanoid pathway of Glycine max in response to Pseudomonas syringae infection. BMC Plant Biol. 2006;6(1):26.

63. Robbins ML, Roy A, Wang P-H, Gaffoor I, Sekhon RS, Marcia MO, Rohila JS, Chopra S. Comparative proteomics analysis by DIGE and iTRAQ provides insight into the regulation of phenylpropanoids in maize. J Proteome. 2013;93:254-75. 
64. Ji H, Kyndt T, He W, Vanholme B, Gheysen G. $\beta$-Aminobutyric acid-induced resistance against root-knot nematodes in rice is based on increased basal defense. Mol Plant-Microbe Interact. 2015;28(5):519-33.

65. Lewis NG, Yamamoto E. Lignin: occurrence, biogenesis and biodegradation. Annu Rev Plant Biol. 1990;41(1):455-96.

66. Nicholson RL, Hammerschmidt R. Phenolic compounds and their role in disease resistance. Annu Rev Phytopathol. 1992;30(1):369-89.

67. Bonello P, Storer AJ, Gordon TR, Wood DL, Heller W. Systemic effects of Heterobasidion annosum on ferulic acid glucoside and lignin of presymptomatic ponderosa pine phloem, and potential effects on barkbeetle-associated fungi. J Chem Ecol. 2003;29(5):1167-82.

68. Gheysen $\mathrm{G}$, Jones J. Molecular aspects of plant-nematode interactions. Plant nematol. 2006:234-54.

69. Miedes E, Vanholme R, Boerjan W, Molina A. The role of the secondary cell wall in plant resistance to pathogens. Front Plant Sci. 2014;5:358

Ready to submit your research? Choose BMC and benefit from:

- fast, convenient online submission

- thorough peer review by experienced researchers in your field

- rapid publication on acceptance

- support for research data, including large and complex data types

- gold Open Access which fosters wider collaboration and increased citations

- maximum visibility for your research: over $100 \mathrm{M}$ website views per year 